\title{
Effects of partial replacement of corn and alfalfa silage with tall fescue hay on total-tract digestibility and lactation performance in dairy cows
}

\author{
R. W. Bender, F. Lopes, D. E. Cook, and D. K. Combs ${ }^{1}$ \\ Department of Dairy Science, University of Wisconsin-Madison, Madison 53706
}

\begin{abstract}
Our objective was to evaluate the effects of replacing either corn or alfalfa silage with tall fescue hay on total-tract neutral detergent fiber (NDF) digestibility and lactation performance in dairy cows. Twenty-four primiparous (75 $\pm 35 \mathrm{~d}$ in milk) and 40 multiparous (68 $\pm 19 \mathrm{~d}$ in milk) Holstein cows were blocked by parity and randomly assigned to 1 of 4 treatment groups in a pen equipped with 32 feeding gates to record intake by cow. Each gate was randomly assigned to 1 treatment group; thus, each cow had access to all 8 gates within the respective treatment and cow was the experimental unit. Treatments were formulated to replace either corn silage (CS) or alfalfa silage (AS) with tall fescue hay (TF) as follows (DM basis): $33 \%$ AS and $67 \%$ CS (control; 33AS67CS), $60 \% \mathrm{TF}$ and $40 \% \mathrm{AS}$ (60TF40AS), $60 \% \mathrm{TF}$ and $40 \% \mathrm{CS}$ (60TF40CS), and $33 \% \mathrm{TF}$ and $67 \%$ CS (33TF67CS). The experiment was a 7 -wk continuous lactation trial with a 2 -wk covariate period. Milk production did not differ among treatments and averaged $40.4 \mathrm{~kg} / \mathrm{d}$. Fat yield and concentration and protein yield and concentration did not differ among treatments and averaged $1.58 \mathrm{~kg} / \mathrm{d}, 3.94 \%, 1.28 \mathrm{~kg} / \mathrm{d}$, and $3.15 \%$, respectively. Dry matter intake was greater for $33 \mathrm{AS} 67 \mathrm{CS}(24.5 \mathrm{~kg} / \mathrm{d})$ compared with $60 \mathrm{TF} 40 \mathrm{CS}$ $(22.1 \mathrm{~kg} / \mathrm{d})$ and 33 TF67CS $(22.7 \mathrm{~kg} / \mathrm{d})$, and tended to be greater than $60 \mathrm{TF} 40 \mathrm{AS}(23.2 \mathrm{~kg} / \mathrm{d})$. In vivo total-tract dry matter digestibility did not differ among treatments and averaged $66.2 \%$. In vivo total-tract NDF digestibility was lower for 33AS67CS (37.8\%) compared with 60TF40AS (44.4\%) and 33TF67CS (45.3\%), and similar to $60 \mathrm{TF} 40 \mathrm{CS}$ (42.4\%). In vivo total-tract NDF digestibility and an estimate of in situ total-tract NDF digestibility were similar between techniques across all treatment diets ( 42.3 vs. $42.6 \%$, respectively). Inclusion of tall fescue grass hay increased the total-tract NDF digestibility of the diet and has the potential to replace
\end{abstract}

Received August 6, 2015.

Accepted February 1, 2016

${ }^{1}$ Corresponding author: dkcombs@wisc.edu corn silage and alfalfa silage and maintain milk production if economically feasible based on current market prices.

Key words: neutral detergent fiber, fiber digestion, tall fescue, dairy cow

\section{INTRODUCTION}

Lactating dairy cow DMI is limited by rumen distension as NDF levels in the ration increase (Allen, 1996), particularly when energy requirements are high (Allen, 2014). Grasses typically have a higher NDF content compared with alfalfa and corn silages (NRC, 2001), and alfalfa and corn silages have become commonplace in high-producing dairy cow rations due to superior DM digestibility (Hoffman, et al., 1993). Improvements in NDF digestibility in corn silage (Ferraretto and Shaver, 2015; Ferraretto et al., 2015) and alfalfa silage (Turnbull et al., 1982) have improved DMI and milk production. Similarly, incorporation of highly digestible NDF in grasses in the ration has the potential to increase DMI and milk production (Rinne et al., 2002; Cherney et al., 2004; Kuoppala et al., 2008) or maintain DMI and increase milk fat (Kendall et al., 2009).

Modern varieties of cool season grasses are bred to have greater NDF digestibility; tall fescue grass can contain greater than $50 \% \mathrm{NDF}$ and have an in vitro 48-h NDF digestibility of up to $75 \%$ of NDF (Brink et al., 2010; Pelletier et al., 2010). Fiber digestibility of grasses can be influenced by many factors. Agronomic practices, such as harvesting earlier (Hoffman et al., 1993; Rinne et al., 2002) or harvesting from spring growth (Rinne et al., 2002; Cherney et al., 2004; Pelletier et al., 2010), increase NDF digestibility. Although varieties of tall fescue with endophytes have been associated with toxicosis and poor cattle performance (Foote et al., 2013), modern varieties of tall fescue have been bred to be free of endophytes and have been shown to improve milk production compared with their infected counterparts (Strahan et al., 1987). Thus, incorporating a cool season, perennial grass, such as endophyte-free tall fescue, may allow for increased digestible NDF in a ration fed to lactating dairy cattle. 
Table 1. Nutrient composition of forages (mean \pm SD)

\begin{tabular}{lccc}
\hline Item (\% of DM, unless noted) & Alfalfa silage & Corn silage & Tall fescue hay \\
\hline DM $(\%$ as fed) & $34.4 \pm 2.6$ & $37.3 \pm 6.2$ & $83.5 \pm 0.6$ \\
OM & $89.6 \pm 1.6$ & $96.4 \pm 0.2$ & $89.3 \pm 1.6$ \\
CP & $21.9 \pm 1.3$ & $7.7 \pm 1.6$ & $14.3 \pm 0.8$ \\
Starch & $0.4 \pm 0.1$ & $35.6 \pm 3.9$ & $1.6 \pm 0.2$ \\
Lignin & $9.4 \pm 0.5$ & $3.6 \pm 0.3$ & $8.1 \pm 1.0$ \\
Ether extract & $3.2 \pm 0.7$ & $3.8 \pm 0.5$ & $3.0 \pm 0.5$ \\
NDF & $44.9 \pm 2.5$ & $38.0 \pm 1.5$ & $64.4 \pm 1.7$ \\
iNDF & $18.9 \pm 2.0$ & $9.2 \pm 0.7$ & $16.9 \pm 1.4$ \\
iNDF $^{1}(\%$ of NDF) & $41.2 \pm 1.2$ & $25.8 \pm 1.2$ & $26.6 \pm 0.3$ \\
pdNDF kd $^{2}(\% / h)$ & $5.1 \pm 0.2$ & $2.1 \pm 0.1$ & $2.9 \pm 0.3$ \\
TTNDFD $^{3}$ (\% of total NDF) & $42.8 \pm 1.4$ & $36.2 \pm 0.3$ & $42.4 \pm 2.2$ \\
\hline
\end{tabular}

${ }^{1} \mathrm{iNDF}=$ indigestible NDF determined by in situ incubation for $288 \mathrm{~h}$.

${ }^{2}$ pdNDF $\mathrm{kd}=$ potentially digestible NDF fraction digestion rate calculated from TTNDFD model.

${ }^{3}$ TTNDFD $=$ predicted total-tract NDF digestibility using in situ TTNDFD model.

A novel tool to predict total-tract NDF digestibility (TTNDFD) has recently been developed (Lopes et al., 2015a) using an in vitro fermentation assay to measure the proportion potentially digestible $\mathrm{NDF}$ and rate of digestion of NDF. Although the model has been validated in high-producing cows at different intake levels (Lopes et al., 2015a), with different alfalfa-to-corn silage ratios (Lopes et al. 2015b), and across several TMR incorporating a diverse array of forage silages (Lopes et al., 2015c), the model has not been validated to in vivo NDF digestion data in grass hay. Thus, the objectives of the present study were to evaluate the effects of replacing either corn silage or alfalfa silage with tall fescue hay on lactation performance and to compare estimates of total-tract fiber digestibility as predicted by the TTNDFD model to in vivo measurements.

\section{MATERIALS AND METHODS}

\section{Description of the Experiment}

The experimental protocol was approved by the Animal Care and Use Committee of the College of Agriculture and Life Sciences at the University of Wisconsin-Madison. Twenty-four primiparous (75 \pm 35 DIM; mean \pm SD) and 40 multiparous $(68 \pm 19$ DIM $)$ lactating Holstein dairy cows were housed in a pen equipped with Insentec Roughage Intake Control system gates (Insentec BV, Marknesse, the Netherlands) in a freestall barn at the University of Wisconsin-Madison Emmons-Blaine Arlington dairy facility. The Roughage Intake Control feeding gates recorded individual cow feed intake continuously. Cows were blocked by parity and randomly assigned to 1 of 4 treatment groups. Each of 32 feeding gates was randomly assigned to 1 treatment group; thus, each cow had access to all 8 gates within the respective treatment group, and cow was the experimental unit.

Treatments were formulated to replace either corn silage (CS) or alfalfa silage (AS) with tall fescue hay (TF; Table 1). Bariane Tall Fescue (Barenbrug USA, Tangent, OR) was planted in separate field plots at a rate of $22.42 \mathrm{~kg} / \mathrm{ha}$ at the University of WisconsinArlington Agricultural Research Station (Arlington, WI) on September 15, 2011, with a no-till drill. For this feeding trial, the forage was cut on June 18, 2013 (first cut), between the boot and heading stage of maturity and baled in large square bales on June 21, 2013. The bales were stored in an enclosed shed for approximately 8 mo before trial initiation.

Diets were formulated to contain similar $\mathrm{CP}$ and starch concentrations, whereas dietary NDF and indigestible NDF (iNDF) levels were allowed to change (Table 2). Treatments were as follows, with diet names abbreviated by the proportion that each forage contributes to the total forage component of each TMR: $33 \%$ AS and $67 \%$ CS (control; 33AS67CS), 60\% TF and $40 \%$ AS (60TF40AS), $60 \%$ TF and $40 \%$ CS (60TF40CS), and $33 \% \mathrm{TF}$ and $67 \%$ CS (33TF67CS). All cows received bST (Posilac, Elanco Animal Health, Greenfield, IN) every $14 \mathrm{~d}$ through the duration of the trial, initiated during the covariate period. The experiment was a continuous lactation trial, beginning with a 2-wk covariate period before 7 wk of assignment to treatment diets.

Cows were fed a TMR with feed delivered 3 times daily at 0300,1200 , and $1500 \mathrm{~h}$, and were offered free access to water. The TMR was mixed once daily before the midday feeding and stored for delivery in the afternoon and the following morning. Cows were fed ad libitum for $10 \%$ refusals. Dry matter content of the forages was measured once weekly, and as-fed ingredient 
proportions were modified accordingly to maintain near constant proportions of feeds on a DM basis.

\section{Data Collection and Laboratory Analyses}

Cows were milked twice daily and milk yield was recorded at each milking. Milk samples were collected from all cows weekly on the evening milking of one day and the subsequent morning milking of the following day throughout the duration of the trial. Samples were composited by cow by week and analyzed for fat, true protein, lactose, MUN concentrations, and SCC by infrared analysis (AgSource Milk Analysis Laboratory, Menomonie, WI) using a Foss FT6000 near infrared spectrophotometer (Foss Electric, Hillerød, Denmark). Average daily yields of fat and protein were calculated from these data for each week. Yields of FCM were calculated according to NRC (2001) equations.

Body weight was recorded on an individual basis weekly. Body condition score (1 to 5 in 0.25 -unit increments; Wildman et al., 1982) was recorded every other week. For both BW and BCS, within each cow, a linear regression using all data points was calculated to determine the change in BW and BCS over time.

Samples of TMR, corn silage, alfalfa silage, tall fescue hay, high-moisture corn, and concentrate mixes were obtained during the covariate period, wk 5 , and wk 7 of the treatment period. Samples were frozen at $-20^{\circ} \mathrm{C}$ until analysis was conducted. All samples were dried at $60^{\circ} \mathrm{C}$ for $48 \mathrm{~h}$ in a forced-air oven to determine DM content. Dried samples were ground to pass a 1-mm Wiley mill (Arthur H. Thomas, Philadelphia, PA) screen and

Table 2. Dietary ingredients and TMR nutrient composition (\% of DM, unless otherwise noted $)^{1}$

\begin{tabular}{|c|c|c|c|c|c|}
\hline Item & Covariate & 33AS67CS & 60TF40AS & 60TF40CS & 33TF67CS \\
\hline \multicolumn{6}{|l|}{ Ingredient } \\
\hline Alfalfa silage & 11.0 & 18.3 & 18.4 & - & - \\
\hline Corn silage & 36.7 & 36.6 & - & 20.0 & 33.1 \\
\hline Tall fescue hay & 9.2 & - & 27.7 & 30.0 & 16.6 \\
\hline High-moisture corn & 22.1 & 23.8 & 38.7 & 30.0 & 26.7 \\
\hline Soybean meal ( $48 \% \mathrm{CP})$ & 14.7 & 14.7 & 9.8 & 14.0 & 16.94 \\
\hline Energy Booster $100^{2}$ & 2.02 & 2.01 & 2.03 & 2.21 & 2.03 \\
\hline Calcium carbonate & 1.28 & 1.28 & 1.29 & 1.40 & 1.66 \\
\hline Sodium bicarbonate & 0.73 & 0.73 & 0.81 & 0.88 & 0.74 \\
\hline Potassium carbonate & 0.37 & 0.37 & - & - & 0.55 \\
\hline Monocalcium phosphate & 0.37 & 0.37 & 0.07 & 0.08 & 0.37 \\
\hline Trace mineral salt ${ }^{3}$ & 0.37 & 0.37 & 0.41 & 0.44 & 0.41 \\
\hline Magnesium-potassium-sulfate ${ }^{4}$ & 0.73 & 0.73 & 0.18 & 0.20 & 0.18 \\
\hline Magnesium oxide & - & 0.33 & 0.18 & 0.20 & 0.28 \\
\hline Vitamin E & 0.02 & 0.02 & 0.02 & 0.02 & 0.04 \\
\hline Vitamin premix, $\mathrm{ADE}^{5}$ & 0.37 & 0.37 & 0.37 & 0.40 & 0.37 \\
\hline Smartamine $\mathrm{M}^{6}$ & 0.05 & 0.05 & 0.06 & 0.06 & 0.04 \\
\hline \multicolumn{6}{|l|}{ Nutrient composition } \\
\hline DM (\% as fed) & 47.5 & 43.2 & 52.7 & 53.2 & 52.7 \\
\hline $\mathrm{OM}$ & 92.7 & 90.2 & 89.2 & 89.0 & 89.8 \\
\hline $\mathrm{CP}$ & 18.0 & 17.9 & 17.5 & 17.1 & 17.3 \\
\hline Starch & 31.3 & 31.2 & 29.3 & 30.1 & 32.4 \\
\hline NDF & 27.8 & 25.3 & 29.8 & 30.5 & 26.7 \\
\hline iNDF $^{7}$ & 7.3 & 7.0 & 8.0 & 6.9 & 6.0 \\
\hline Ether extract & 5.1 & 6.3 & 5.5 & 5.6 & 5.9 \\
\hline \multicolumn{6}{|c|}{$\begin{array}{l}\text { Penn State Particle Separator } \text { sieves }^{8}(\% \text { as fed retained, } \pm \\
\text { SD) }\end{array}$} \\
\hline $19 \mathrm{~mm}$ & $6.9 \pm 0.4$ & $7.9 \pm 0.2$ & $9.9 \pm 3.0$ & $12.2 \pm 4.5$ & $9.3 \pm 3.1$ \\
\hline $8 \mathrm{~mm}$ & $42.5 \pm 1.1$ & $45.5 \pm 1.4$ & $30.7 \pm 2.5$ & $30.0 \pm 1.5$ & $24.6 \pm 0.3$ \\
\hline $1.18 \mathrm{~mm}$ & $37.9 \pm 0.8$ & $36.3 \pm 0.6$ & $42.4 \pm 1.0$ & $41.0 \pm 1.3$ & $46.9 \pm 1.6$ \\
\hline Bottom pan & $12.7 \pm 0.8$ & $10.3 \pm 0.7$ & $16.9 \pm 0.5$ & $16.9 \pm 1.8$ & $19.2 \pm 1.7$ \\
\hline
\end{tabular}

${ }^{1}$ Treatments: TMR with the forage portion composed (DM basis) of 33\% alfalfa silage (AS) and $67 \%$ corn silage (CS; control; 33AS67CS), $60 \%$ tall fescue (TF) and 40\% AS (60TF40AS), 60\% TF and 40\% CS (60TF40CS), and 33\% TF and 67\% CS (33TF67CS).

${ }^{2}$ Minimum $98 \%$ total fatty acids (MSC Company, Dundee, IL).

${ }^{3}$ Contained $88 \% \mathrm{NaCl} ; 0.002 \% \mathrm{Co} ; 0.2 \% \mathrm{Cu} ; 0.012 \%$ I; $0.18 \%$ Fe; $0.8 \% \mathrm{Mn} ; 0.006 \%$ Se; $1.4 \% \mathrm{Zn}$.

${ }^{4}$ Dynamate $(11 \% \mathrm{Mg}, 18 \% \mathrm{~K}, 22 \% \mathrm{~S}$; The Mosaic Co., Plymouth, MN).

${ }^{5}$ Vitamin A 3,300,000 IU/kg; vitamin D 1,100,000 IU/kg; vitamin E 11,000 IU $/ \mathrm{kg}$.

${ }^{6}$ Smartamine M, 70\% Methionine (Adisseo, SAS, France).

${ }^{7}$ iNDF $=$ indigestible NDF determined by in situ incubation for $288 \mathrm{~h}$.

${ }^{8}$ Particle size was measured using the Penn State Particle Size Separator as described by Kononoff et al. (2003). 
sent to Rock River Laboratory Inc. (Watertown, WI) for further analysis. Absolute DM was determined by oven-drying at $105^{\circ} \mathrm{C}$ for $3 \mathrm{~h}$ (method 2.2.2.5; NFTA, 1993). All samples were analyzed for DM, CP (method 990.03; AOAC International, 2006), ether extract (method 920.39; AOAC International, 2006), and starch (Hall, 2009). Acid detergent lignin was determined via method 973.18 (AOAC International, 2006), modified to use $1.0 \mathrm{~g}$ per sample in each Ankom F57 bag (Ankom Technology, Macedon, NY). All Ankom bags were washed in acetone, dried in a fume hood, and further dried in a forced-air oven at $60^{\circ} \mathrm{C}$ for $1 \mathrm{~h}$ before weighing the sample. Neutral detergent fiber was determined using $\alpha$-amylase and sodium sulfite (Van Soest et al., 1991). Indigestible NDF was determined by in situ rumen incubation for $288 \mathrm{~h}$ (NorFor, 2011). Total-tract NDF digestibility was determined using the procedures described in Lopes et al. (2015a) modified to use the in situ 288-h iNDF estimates to determine the potentially digestible NDF fraction. In situ NDF digestibility was determined via incubation of $0.5 \mathrm{~g}$ of dried and ground TMR constituents from wk 5 and 7 for 18, 24, 30, and $48 \mathrm{~h}$, then subsequently analyzed for NDF, as indicated above. Particle size distribution of treatment diets were determined as described by Kononoff et al. (2003), utilizing 2 samples from each treatment TMR.

Apparent total-tract digestibilities of DM, OM, and NDF were determined using iNDF as an internal marker. Six fecal grab samples were collected from each cow at 8 - to 12 -h intervals covering every 4 -h period over 2 consecutive days during wk 5 and 7 of the treatment period. Ort samples were collected daily during the fecal sampling period. Treatment TMR samples were composited by week, fecal samples were composited by cow, and ort samples were composited by treatment within week. The composited treatment TMR and ort samples were analyzed for DM, OM, NDF, starch, and iNDF, as defined above. The composited fecal samples were analyzed for NDF and iNDF. In vivo total-tract nutrient digestibilities were calculated from iNDF and nutrient concentrations in the orts-adjusted diet and feces.

\section{Statistical Analyses}

Data were analyzed as a randomized, complete-block design with a covariate using the MIXED procedure of SAS (version 9.4, SAS Institute Inc., Cary, NC). The model included parity, treatment, week, and the relevant interactions as fixed effects, and cow within treatment as a random effect. Week of treatment was included as a repeated measure using the compound symmetry structure to account for autocorrelated errors. Means were determined using the least squares means statement, and treatment means were compared using the Bonferroni $t$-test option after a significant $(P<0.05)$ overall treatment $F$-test. Interaction effects were partitioned using the SLICE options of SAS (version 9.4, SAS Institute Inc.).

Comparison of in vivo and in situ TTNDFD was conducted using the MIXED procedure of SAS (version 9.4, SAS Institute Inc.). The model included method of TTNDFD determination (in vivo and in situ) as a fixed effect. Means were determined using the least squares statement, and treatment means were compared using the Bonferroni $t$-test option. Statistical significance and trends were considered at $P \leq 0.05$ and $P>0.05$ to $P$ $\leq 0.10$, respectively.

\section{RESULTS AND DISCUSSION}

Nineteen cows were removed from the trial for health and behavior reasons. One cow could not be trained to the feeding gates. Two were removed for health reasons, one for severe mastitis, and one for lameness. Sixteen cows were also removed because they habitually consumed feed from gates in which they were not assigned that totaled at least $5 \%$ of their feed intake. These 19 cows were not used in the statistical analysis.

\section{Forage and Diet Composition}

Nutrient composition and in situ fiber digestibility of the forages used in the treatment diets are in Table 1. Nutrient composition was typical of good-quality forages used in lactating rations in the Upper Midwest of the United States. Tall fescue hay had the highest concentration of NDF, followed by alfalfa silage and corn silage. Indigestible NDF (\% of DM) was higher for alfalfa silage and tall fescue hay, compared with corn silage. The rate of digestion of the potentially digestible NDF fraction was greatest for alfalfa silage $(5.1 \% / \mathrm{h})$, lowest for corn silage $(2.1 \% / \mathrm{h})$, and intermediate for tall fescue hay $(2.9 \% / \mathrm{h})$. As a result, the TTNDFD $(\%$ of total NDF) was similar between alfalfa silage and tall fescue hay (42.8\% and $42.4 \%$, respectively) and lower for corn silage $(36.2 \%)$. Tall fescue has previously been reported as having a greater NDF content and greater NDF digestibility when compared with corn and alfalfa silages (Cherney et al., 2004), but similar to other perennial grasses (Cherney et al., 1993) harvested at a similar maturity.

Dietary ingredients, nutrient composition, and particle sizing of the treatment and covariate diets are listed in Table 2. Treatment TMR were formulated to replace corn silage $(60 \mathrm{TF} 40 \mathrm{AS})$ or alfalfa silage $(60 \mathrm{TF} 40 \mathrm{CS}$ and 33TF67CS) with tall fescue hay while maintaining similar $\mathrm{CP}$ and starch levels based on initial forage 
test results taken before initiation of the trial. Neutral detergent fiber was higher for the diets incorporating tall fescue at a high rate $(60 \mathrm{TF} 40 \mathrm{AS}$ and 60TF40CS; average $=30.2 \%$ ) compared with the 33AS67CS diet $(25.3 \%)$ and the diet with a moderate amount of tall fescue incorporation (33TF67CS; 26.7\%). The proportion of TMR retained in the top pan of the Penn State Particle Separator (Nasco, Fort Atkinson, WI) increased with inclusion of tall fescue hay as expected due to the longer particles of the hay. The second screen had a higher proportion of TMR in the control compared with the tall fescue diets likely due to the higher silage inclusion rate, which had smaller particles than the hay.

\section{DMI, Milk Yield, and Milk Components}

Treatment effects on lactation performance are reported in Table 3. Milk production did not differ among treatments and averaged $40.4 \mathrm{~kg} / \mathrm{d}$. Dry matter intake was greater $(P<0.05)$ for the 33AS67CS diet compared with the 60TF40CS and 33TF67CS diets, and tended $(P=0.07)$ to be greater than the 60TF40AS diets. The 3 diets incorporating tall fescue hay had similar DMI and averaged $22.7 \mathrm{~kg} / \mathrm{d}$. A treatment $\times$ week interaction for DMI is shown in Figure 1, where DMI was similar among all treatments for treatment wk 1, 2, 3, and 6 , but was greater $(P<0.05)$ for the 33AS67CS treatment compared with 33TF67CS treatment in wk 4,5 , and 7 , greater for the 33AS67CS treatment compared with the 60TF40CS treatment in wk 5 and 7 , and greater for the 33AS67CS treatment compared with the $60 \mathrm{TF} 40 \mathrm{AS}$ in wk 7.

The present study differs from Verbeten (2012), which reported that DMI and milk production did not

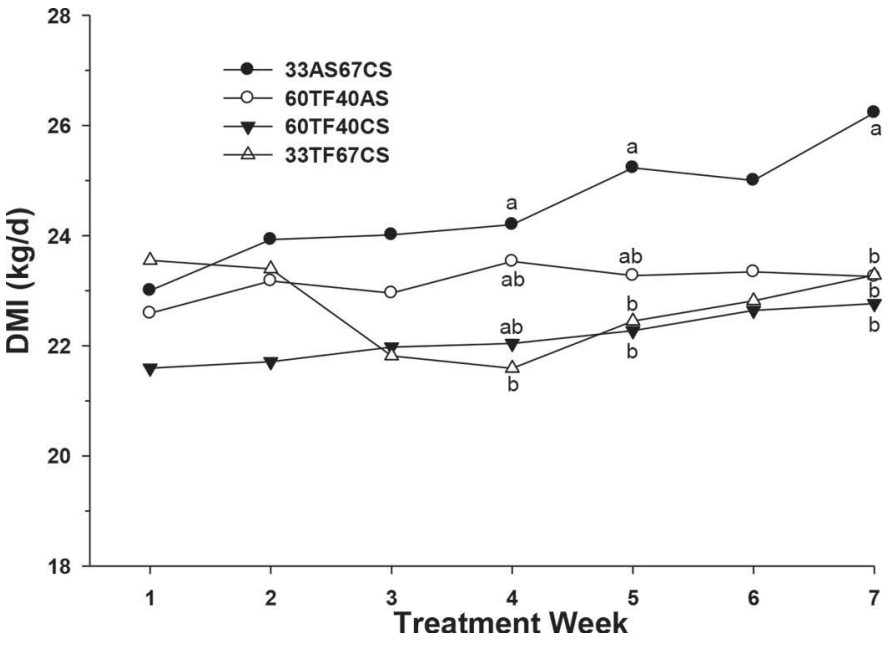

Figure 1. Least squared means of DMI by week for cows consuming TMR with the forage portion composed (DM basis) of $33 \%$ alfalfa silage and $67 \%$ corn silage (control; 33AS67CS), $60 \%$ tall fescue hay and $40 \%$ alfalfa silage (60TF40AS), $60 \%$ tall fescue hay and $40 \%$ corn silage (60TF40CS), and 33\% tall fescue hay and $67 \%$ corn silage (33TF67CS). Within week, means with different letters (a,b) differ $(P$ $<0.05)$.

differ when meadow fescue silage, tall fescue silage, or wheat straw was added to a low-NDF $(23.4 \%)$ diet to supplement digestible NDF (meadow fescue diet, $26.0 \%$ NDF, and tall fescue silage diet, $26.5 \%$ NDF). However, the diets in the present study incorporating tall fescue grass are all higher in NDF than Verbeten (2012), suggesting that gut fill could potentially be limiting DMI (Allen, 1996) in the diets incorporating tall fescue. Similarly, 2 Finnish studies (Kuoppala et al., 2008, 2010) fed a combination of timothy and meadow fescue silages to lactating cows and observed that the silages with higher NDF limited DMI as well; however, these

Table 3. Effects of tall fescue (TF) hay incorporation on lactation performance

\begin{tabular}{|c|c|c|c|c|c|c|c|c|}
\hline \multirow[b]{2}{*}{ Item } & \multicolumn{4}{|c|}{ Treatment $^{1}$} & \multirow[b]{2}{*}{ SEM } & \multicolumn{3}{|c|}{$P$-value ${ }^{2}$} \\
\hline & 33AS67CS & 60TF40AS & 60TF40CS & 33TF67CS & & Trt & Week & Trt $\times$ week \\
\hline Milk (kg/d) & 42.3 & 39.2 & 39.1 & 41.0 & 1.2 & 0.19 & 0.03 & 0.83 \\
\hline $4.0 \% \mathrm{FCM}^{3}(\mathrm{~kg} / \mathrm{d})$ & 41.2 & 39.8 & 38.2 & 41.0 & 1.1 & 0.15 & 0.01 & 0.49 \\
\hline DMI $(\mathrm{kg} / \mathrm{d})$ & $24.5^{\mathrm{a}}$ & $23.2^{\mathrm{ab}}$ & $22.1^{\mathrm{b}}$ & $22.7^{\mathrm{b}}$ & 0.38 & $<0.01$ & $<0.01$ & $<0.01$ \\
\hline $4 \% \mathrm{FCM} / \mathrm{DMI}(\mathrm{kg} / \mathrm{kg})$ & 1.69 & 1.71 & 1.71 & 1.78 & 0.04 & 0.37 & $<0.01$ & 0.09 \\
\hline Fat $(\%)$ & 3.88 & 3.94 & 3.83 & 4.09 & 0.13 & 0.33 & 0.35 & 0.11 \\
\hline Protein (\%) & 3.18 & 3.08 & 3.14 & 3.19 & 0.05 & 0.26 & $<0.01$ & $<0.01$ \\
\hline Lactose $(\%)$ & 4.84 & 4.90 & 4.92 & 4.91 & 0.02 & 0.18 & 0.04 & $<0.01$ \\
\hline $\mathrm{SCC}$ & 67.8 & 50.5 & 90.0 & 84.0 & 25.7 & 0.57 & 0.67 & 0.63 \\
\hline MUN (mg/dL) & $14.0^{\mathrm{a}}$ & $12.7^{\mathrm{b}}$ & $13.4^{\mathrm{ab}}$ & $13.6^{\mathrm{ab}}$ & 0.4 & 0.03 & $<0.01$ & $<0.01$ \\
\hline BW change $(\mathrm{kg} / \mathrm{d})$ & 0.66 & 0.60 & 0.55 & 0.57 & 0.09 & 0.86 & & \\
\hline BCS change (units/wk) & 0.02 & 0.01 & 0.00 & 0.01 & 0.01 & 0.65 & & \\
\hline
\end{tabular}

${ }_{\mathrm{a}, \mathrm{b}}$ Means within a row with different superscripts differ $(P<0.05)$.

${ }^{1}$ Treatments: TMR with the forage portion composed (DM basis) of 33\% alfalfa silage (AS) and $67 \%$ corn silage (CS; Control; 33AS67CS), 60\% TF and 40\% AS (60TF40AS), 60\% TF and 40\% CS (60TF40CS), and 33\% TF and 67\% CS (33TF67CS).

${ }^{2}$ Trt $=$ treatment; Trt $\times$ week $=$ treatment by week interaction.

${ }^{3} 4.0 \%$ FCM yield $=(0.4 \times \mathrm{kg}$ of milk $)+(15.0 \times \mathrm{kg}$ of fat $)$. 
studies saw a corresponding decrease in milk production concomitant with the decreased DMI. Cherney et al. (2004) evaluated the effects of feeding alfalfa silage compared with orchardgrass or tall fescue silage on lactation performance in high-producing cows and found that the tall fescue diet, which was greatest in NDF among the diets, had significantly lower DMI compared with the lower-NDF diets. Milk production followed a similar pattern and was decreased compared with the lower NDF diets. The week $\times$ treatment interaction for DMI in the present study was not observed, to our knowledge, in other studies feeding grasses; however, many of these are Latin square design (Fisher et al., 1993; Broderick et al., 2002; Rinne et al., 2002; Kuoppala et al., 2008, 2010) or other trial designs of shorter periods (Hoffman et al., 1998; Cherney et al., 2004), which do not allow for a pronounced interaction over time. Strahan et al. (1987; 4 or 8 wk) and Verbeten (2012; 98 d) conducted trials of longer duration and did not report an interaction over time.

The production of $4.0 \%$ FCM (Table 3 ) did not differ among treatments and averaged $40.1 \mathrm{~kg} / \mathrm{d}$. Feed efficiency, measured as $4 \% \mathrm{FCM} / \mathrm{DMI}(\mathrm{kg} / \mathrm{kg})$ in the present study, did not differ among treatments and averaged 1.72. A tendency $(P=0.09)$ for a treatment $\times$ week interaction for feed efficiency was observed, likely due to the treatment $\times$ week interaction observed for DMI, as previously discussed.

The effects of tall fescue hay incorporation on milk composition are also reported in Table 3. No effect of treatment was noted on milk fat, protein, or lactose yield or composition. However, a significant treatment $\times$ week interaction was observed for both protein $(P$ $<0.01)$ and lactose $(P<0.01)$ composition. The lack of an effect on milk fat was consistent with another study (R. W. Bender, F. Lopes, D. E. Cook, and D. K. Combs, unpublished data) that reported no difference in rumination between the treatments. Similarly, Cherney et al. (2004) reported no change in yield or composition of fat, protein, or lactose when tall fescue replaced alfalfa. However, Verbeten (2012) reported higher milk fat composition and yield when supplementing tall fescue and meadow fescue silage, but this was compared with a control diet with lower NDF levels than the control in the present study (23.4 vs. $25.3 \%$, respectively). Rumination was not reported in any of these studies.

Milk SCC did not differ among treatments. To our knowledge, no other studies reported significant effects of tall fescue hay incorporation on milk SCC. Milk urea nitrogen was greater $(P=0.03)$ for 33AS67CS compared with the 60TF40AS, but similar among other treatments. However, this was likely due to higher level of $\mathrm{CP}$, creating an excess of RDP in the control diet
(Broderick and Clayton, 1997; Huhtanen and Hristov, 2009) compared with the other treatments.

Change in BW and BCS did not differ among treatments and averaged $0.60 \mathrm{~kg} / \mathrm{d}$ and $0.01 \mathrm{units} / \mathrm{wk}$, respectively. Across all treatments, BW for cows averaged $648 \pm 87 \mathrm{~kg}$ (primiparous $583 \pm 65 \mathrm{~kg}$; multiparous 688 $\pm 73 \mathrm{~kg}$ ) at trial initiation and $690 \pm 91 \mathrm{~kg}$ (primiparous $631 \pm 67 \mathrm{~kg}$; multiparous $727 \pm 84 \mathrm{~kg}$ ) at completion of the trial. Similarly, other studies feeding grass forages reported no difference in BW or BCS change (Cherney et al., 2004; Verbeten, 2012).

\section{Nutrient Digestibility}

Milk production, intake, and digestibility data are presented in Table 4 . No treatment $\times$ parity interactions were noted for any of the milk production, intake, nutrient digestibility, or feed efficiency data. Milk production from wk 5 and 7 were similar to the whole trial averages and did not differ among treatments. Dry matter intake during wk 5 and 7 was greater $(P<0.01)$ in the 33AS67CS treatment compared with the 60TF40CS treatment and tended $(P=0.08)$ to be greater than the 33TF67CS treatment. Apparent total-tract DM digestibility tended $(P=0.07)$ to be greater for the 33TF67CS treatment compared with the 60TF40CS treatment, but was similar among all treatments and averaged $66.2 \%$. As a result, the 33AS67CS treatment had greater $(P<0.01)$ total-tract DM digested compared with the 60TF40CS treatment.

Organic matter intake followed a similar pattern: 33AS67CS had a greater $(P<0.01)$ intake than 60TF40CS, and 60TF40AS tended $(P=0.10)$ to have a greater intake compared with 60TF40CS. Apparent total-tract OM digestibility was greater for 33TF67CS compared with the 60TF40AS $(P=0.02)$ and 60TF40CS $(P=$ 0.02 ) treatments. As a result, the 33AS67CS treatment had greater $(P<0.01)$ and 33TF67CS tended $(P=$ $0.09)$ to have greater total-tract OM digested compared with the 60TF40CS treatment.

Intake of NDF was greater $(P<0.05)$ for $60 \mathrm{TF} 40 \mathrm{AS}$ compared with all other treatments, likely due to the elevated NDF level in the diet and high DMI compared with the other treatments (Tables 2 and 4). As a percentage of $\mathrm{BW}, \mathrm{NDF}$ intake tended to be greater for $60 \mathrm{TF} 40 \mathrm{AS}$ than either 33AS67CS $(P=0.07)$ or 33TF$67 \mathrm{CS}(P=0.08)$. Apparent TTNDFD was lower for the 33AS67CS treatment compared with the 40TF60AS ( $P$ $=0.01)$ and 33TF67CS $(P<0.01)$ treatments. As a result, the 33AS67CS treatment had less NDF digested compared with 60TF40AS $(P<0.01)$ and 33TF67CS $(P=0.02)$. The 60TF40AS treatment tended $(P=$ $0.05)$ to increase the amount of NDF digested compared with the 60TF40CS treatment. 
Indigestible NDF intake was significantly $(P<0.05)$ greater for the 33AS67CS and 60TF40AS treatments compared with the 60TF40CS and 33TF67CS treatments, likely due to the elevated iNDF concentration of the alfalfa silage combined with the higher intake from the 33AS67CS and 60TF40AS treatments. Indigestible NDF intake as a percentage of BW was significantly $(P$ $<0.05)$ lower for 33TF67CS compared with all other treatments, and the 60TF40CS treatment was significantly lower than either the 33AS67CS $(P<0.01)$ or 60TF40AS $(P<0.01)$ treatments.

As DMI decreased between treatments, DM and OM digested decreased. However, the quantity of NDF digested increased despite the decline in DMI between treatments. This is because a greater proportion of digested OM came from NDF when tall fescue hay was incorporated into the diets. Additionally, as DMI decreased between treatments, NDF intake both in kilograms per day and as a percentage of BW increased relative to the control, whereas iNDF intake both in kilograms per day and as a percentage of BW decreased for 60TF40CS and 33TF67CS and only slightly increased for $60 \mathrm{TF} 40 \mathrm{AS}$ relative to $33 \mathrm{AS} 67 \mathrm{CS}$ (Table 4). This can likely be attributed to the fact that, although alfalfa silage has the highest digestion rate of potentially digestible NDF, tall fescue hay still has a higher digestion rate of potentially digestible NDF compared with corn silage and a much higher level of NDF relative to either alfalfa or corn silage (Table 1).

Grant (2015) suggested that grasses have less fragile NDF compared with legumes, and therefore grasses tend to increase rumen gut fill and result in slower passage from the rumen. In addition, Grant (2015) observed that feeding a high-forage diet with either conventional corn silage or BMR corn silage increases both rumination and time spent eating. In contrast, Kammes and Allen (2012) suggest that when feeding TMR diets composed of orchardgrass compared with alfalfa, rumination time was similar and time spent eating tended $(P=0.10)$ to be greater for the alfalfa diet. Similar to the latter study, the present study and another trial (R. W. Bender, F. Lopes, D. E. Cook, and D. K. Combs, unpublished data) reported that, despite diets ranging in amount of NDF (ranging from $25.3 \%$ to $30.5 \% \mathrm{NDF}$ ) and forage source (alfalfa silage, corn silage, tall fescue grass hay), no effect $(P>0.05)$ on rumination (averaged 481.0 min among all treatments) or eating time (averaged $222.2 \mathrm{~min}$ among all treatments) was observed. In addition, no treatment effect $(P>0.05)$ on rumination time per unit of NDF (averaged $75.4 \mathrm{~min} / \mathrm{kg}$ of NDF intake among all treatments) or DM (averaged $21.5 \mathrm{~min} / \mathrm{kg}$ of DMI among

Table 4. Effects of tall fescue hay incorporation on milk production, intake, and apparent total-tract digestibility of DM, OM, and NDF during wk 5 and 7

\begin{tabular}{|c|c|c|c|c|c|c|}
\hline Item & \multicolumn{4}{|c|}{ Treatment $^{1}$} & SEM & $P$-value \\
\hline Milk, $\mathrm{kg} / \mathrm{d}$ & 42.2 & 40.3 & 39.0 & 39.6 & 1.43 & 0.39 \\
\hline \multicolumn{7}{|l|}{ DM } \\
\hline Intake $(\mathrm{kg} / \mathrm{d})$ & $24.9^{\mathrm{a}}$ & $23.5^{\mathrm{ab}}$ & $21.4^{\mathrm{b}}$ & $22.6^{\mathrm{ab}}$ & 0.68 & $<0.01$ \\
\hline Total-tract digestibility (\%) & 66.3 & 65.3 & 65.0 & 68.0 & 0.87 & 0.04 \\
\hline Total-tract digested $(\mathrm{kg})$ & $16.5^{\mathrm{a}}$ & $15.3^{\mathrm{ab}}$ & $13.9^{\mathrm{b}}$ & $15.3^{\mathrm{ab}}$ & 0.48 & $<0.01$ \\
\hline Total-tract digestibility (\%) & $68.7^{\mathrm{ab}}$ & $67.4^{\mathrm{b}}$ & $67.4^{\mathrm{b}}$ & $70.6^{\mathrm{a}}$ & 0.81 & $<0.01$ \\
\hline Total-tract digested $(\mathrm{kg})$ & $15.7^{\mathrm{a}}$ & $14.4^{\mathrm{ab}}$ & $13.1^{\mathrm{b}}$ & $14.6^{\mathrm{ab}}$ & 0.44 & $<0.01$ \\
\hline \multicolumn{7}{|l|}{ NDF } \\
\hline Intake $(\mathrm{kg} / \mathrm{d})$ & $6.25^{\mathrm{b}}$ & $7.11^{\mathrm{a}}$ & $6.36^{\mathrm{b}}$ & $6.33^{\mathrm{b}}$ & 0.19 & $<0.01$ \\
\hline Intake $(\%$ of $\mathrm{BW})$ & 0.96 & 1.05 & 1.00 & 0.97 & 0.03 & 0.04 \\
\hline Total-tract digestibility (\%) & $37.8^{\mathrm{b}}$ & $44.4^{\mathrm{a}}$ & $42.4^{\mathrm{ab}}$ & $45.3^{\mathrm{a}}$ & 1.50 & $<0.01$ \\
\hline Total-tract digested $(\mathrm{kg})$ & $2.35^{\mathrm{b}}$ & $3.17^{\mathrm{a}}$ & $2.74^{\mathrm{ab}}$ & $2.86^{\mathrm{a}}$ & 0.12 & $<0.01$ \\
\hline \multicolumn{7}{|l|}{$\mathrm{iNDF}^{2}$} \\
\hline Milk/digested NDF $(\mathrm{kg} / \mathrm{kg})$ & $17.7^{\mathrm{a}}$ & $13.1^{\mathrm{b}}$ & $15.5^{\mathrm{ab}}$ & $13.7^{\mathrm{ab}}$ & 1.11 & 0.01 \\
\hline In situ TTNDFD ${ }^{3}(\%)$ & 41.6 & 44.0 & 42.5 & 42.4 & 1.51 & 0.53 \\
\hline
\end{tabular}

${ }^{\text {a-c }}$ Means within a row with different superscripts differ $(P<0.05)$.

${ }^{1}$ Treatments: TMR with the forage portion composed (DM basis) of $33 \%$ alfalfa silage (AS) and $67 \%$ corn silage (CS; Control; 33AS67CS), 60\% $\mathrm{TF}$ and $40 \% \mathrm{AS}$ (60TF40AS), $60 \% \mathrm{TF}$ and $40 \% \mathrm{CS}$ (60TF40CS), and $33 \% \mathrm{TF}$ and $67 \% \mathrm{CS}$ (33TF67CS).

${ }^{2} \mathrm{iNDF}=$ indigestible NDF determined by in situ incubation for $288 \mathrm{~h}$.

${ }^{3}$ TTNDFD $=$ predicted total-tract NDF digestibility using in situ TTNDFD model. 
all treatments) was observed (R. W. Bender, F. Lopes, D. E. Cook, and D. K. Combs, unpublished data), suggesting that highly digestible grasses could provide an alternate source of NDF with no effect on rumen fill and rumination.

Milk production per DMI $(\mathrm{kg} / \mathrm{kg})$ and milk production per OM intake $(\mathrm{kg} / \mathrm{kg})$ were similar across all treatments and averaged 1.72 and $1.88 \mathrm{~kg} / \mathrm{kg}$, respectively. Milk production per digested NDF $(\mathrm{kg} / \mathrm{kg})$ was significantly greater $(P=0.02)$ for the 33AS67CS treatment compared with the 60TF40AS treatment and tended $(P=0.05)$ to be greater than the 33TF67CS treatment.

Cherney et al. (1993) reported that DM digestibility of cool season grasses declined as maturity increased; however, that was in an in vitro setting. Rinne et al. (2002) and Kuoppala et al. (2008, 2010) evaluated apparent nutrient digestibilities by dairy cows of DM, $\mathrm{OM}$, and NDF and found that as maturity of grass silage increased, digestibility of the respective nutrients decreased. Cherney et al. (2004) compared cool season grasses as a replacement for alfalfa in lactating cows. Although in vivo NDF digestiblities were not evaluated, in vitro results indicated that incorporating tall fescue into the TMR improved NDF digestibility by nearly $20 \%$ compared with the alfalfa-based TMR (76.3 vs. 58.1, $P<0.05)$. Collectively, these results, along with similar results by Verbeten (2012) and the present study, indicate that feeding a highly digestible source of NDF from a cool season immature grass could be a viable replacement for corn silage and alfalfa silage in a high-producing dairy cow ration.

\section{In Situ Versus In Vivo NDF Digestibility}

In situ total-tract NDF digestibility is also reported in Table 4. The predicted TTNDFD values based on in situ $K_{d}$ (rate of ruminal NDF degradation) and iNDF were similar across diets and averaged $42.6 \%$ of NDF. A comparison of in situ versus in vivo TTNDFD is reported in Table 5. Across all treatments, method of TTNDFD determination was similar and averaged $42.5 \%$. In vivo changes in passage rate are reflected in in vivo TTNDFD; however, in situ TTNDFD uses a

Table 5. Comparison of in situ to in vivo TTNDFD ${ }^{1}$

\begin{tabular}{lcccc}
\hline & \multicolumn{2}{c}{ Method } & & \\
\cline { 2 - 3 } Item & In vivo & In situ $^{2}$ & SEM & $P$-value \\
\hline TTNDFD (\%) & 42.3 & 42.6 & 1.2 & 0.86 \\
\hline
\end{tabular}

${ }^{1}$ TTNDFD $=$ total-tract NDF digestibility.

${ }^{2}$ Predicted total-tract NDF digestibility using the in situ TTNDFD model. predetermined passage rate of $2.67 \% / \mathrm{h}$ (Lopes et al., 2015c).

The higher standard error of the mean associated with the in situ TTNDFD values was likely due to the low number of replicates compared with the in vivo data. The in vivo data used each cow as an experimental unit; thus, each treatment had 16 cows initially assigned to determine in vivo TTNDFD in 2 different weeks of the trial (5 and 7). As the in situ data were calculated using forage samples from these same $2 \mathrm{wk}$ and not individual cow data, the power is reduced. Thus, the comparison between in situ and in vivo data was conducted using one value from each of 2 wk for each diet for both in vivo and in situ data to conduct a fair analysis.

Lopes et al. (2015c) validated an in vitro model to predict in vivo TTNDFD. The present study measured in situ TTNDFD, but applied these data to the same equation from Lopes et al. (2015c) to predict in vivo TTNDFD from in vitro TTNDFD. Our results follow a very similar pattern as the relationship among the 21 diets from Lopes et al. (2015c).

\section{CONCLUSIONS}

Replacing corn silage and alfalfa silage with tall fescue hay decreased DMI but maintained milk production and milk components compared with the control treatment in high-producing dairy cows, with no effect on rumination and eating time. Apparent total-tract DM digestibility did not differ from the control diet, but apparent TTNDFD was greater in treatments incorporating tall fescue hay. Thus, despite the depression in feed intake, the higher NDF digestibility in diets incorporating tall fescue hay resulted in similar milk production. In addition, in situ TTNDFD were similar to in vivo TTNDFD data. Results of this study suggest that inclusion of tall fescue grass hay increased the TTNDFD of the diet and has the potential to replace corn silage and alfalfa silage and maintain milk production in lactating dairy cow rations. Inclusion of tall fescue grass hay increased the total-tract NDF digestibility of the diet and has the potential to replace corn silage and alfalfa silage and maintain milk production if economically feasible based on current market prices.

\section{ACKNOWLEDGMENTS}

The authors acknowledge USDA (Washington, DC) Hatch NEW-1044 Multi-State Research Formula fund \#WIS01635 for the funding of this study. In addition, we thank Mike Peters, Sandy Trower, Sandy Bertics, and other staff at the University of Wisconsin-Madison Blaine Dairy for animal care and management. The 
authors acknowledge the numerous UW-Madison Dairy Nutrition graduate and undergraduate students for assistance with sampling, including Shane Fredin, Lauryn Vanderwerff, Luiz Ferraretto, Matias Aguerre, Tawny Chandler, Tiago Barros, Derek Donnelly, Kathryn Ruh, as well as Franscisco Contreras (UW-Madison) for assistance with data collection and analysis.

\section{REFERENCES}

Allen, M. S. 1996. Physical constraints on voluntary intake of forages by ruminants. J. Anim. Sci. 74:3063-3075.

Allen, M. S. 2014. Drives and limits to feed intake in ruminants. Anim. Prod. 54:1513-1524.

AOAC International. 2006. Official Methods of Analysis. 18th ed. AOAC International, Arlington, VA.

Brink, G. E., M. D. Casler, and N. P. Martin. 2010. Meadow fescue, tall fescue, and orchardgrass response to defoliation management. Agron. J. 102:667-674.

Broderick, G. A., and M. K. Clayton. 1997. A statistical evaluation of animal and nutritional factors influencing concentrations of milk urea nitrogen. J. Dairy Sci. 80:2964-2971.

Broderick, G. A., R. G. Koegel, R. P. Walgenbach, and T. J. Kraus, 2002. Ryegrass or alfalfa silage as the dietary forage for lactating dairy cows. J. Dairy Sci. 85:1894-1901.

Cherney, D. J. R., J. H. Cherney, and L. E. Chase. 2004. Lactation performance of Holstein cows fed fescue, orchardgrass, or alfalfa silage. J. Dairy Sci. 87:2268-2276.

Cherney, D. J. R., J. H. Cherney, and R. F. Lucey. 1993. In vitro digestion kinetics and quality of perennial grasses as influenced by forage maturity. J. Dairy Sci. 76:790-797.

Ferraretto, L. F., A. C. Fonseca, C. J. Sniffen, A. Formigoni, and R. D. Shaver. 2015. Effect of corn silage hybrids differing in starch and neutral detergent fiber digestibility on lactation performance and total-tract nutrient digestibility by dairy cows. J. Dairy Sci. 98:395-405.

Ferraretto, L. F., and R. D. Shaver. 2015. Effects of whole-plant corn silage hybrid type on intake digestion, ruminal fermentation, and lactation performance by dairy cows through a meta-analysis. J. Dairy Sci. 98:2662-2675.

Fisher, L. J., S. Bittman, J. A. Shelford, B. D. Mason, and D. E. Hunt 1993. A comparison of tall fescue and orchardgrass silages for lactating cows. Can. J. Anim. Sci. 73:907-914.

Foote, A. P., N. B. Kristensen, J. L. Klotz, D. H. Kim, A. F. Koontz, K. R. McLeod, L. P. Bush, F. N. Shrick, and D. L. Harmon. 2013. Ergot alkaloids from endophyte-infected tall fescue decrease reticuloruminal epithelial blood flow and volatile fatty acid absorption from the washed reticulorumen. J. Anim. Sci. 91:5366-5378.

Grant, R. 2015. Making milk with forage: Understanding rumen fiber dynamics. Pages 63-69 in Four-State Dairy Nutrition and Management Conference, Dubuque, IA. Wisconsin Agri-Business Association, Madison.

Hall, M. B. 2009. Determination of starch, including maltooligosaccharides, in animal feeds: Comparison of methods and a method recommended for AOAC collaborative study. J. AOAC Int. 92:42-49.

Hoffman, P. C., D. K. Combs, and M. D. Casler. 1998. Performance of lactating dairy cows fed alfalfa silage or perennial ryegrass silage. J. Dairy Sci. 81:162-168.

Hoffman, P. C., S. J. Sievert, R. D. Shaver, D. A. Welch, and D. K Combs. 1993. In situ dry matter, protein, and fiber degradation of perennial forages. J. Dairy Sci. 76:2632-2643.
Huhtanen, P., and A. N. Hristov. 2009. A meta-analysis of the effects of dietary crude protein concentration and degradability on milk protein yield and milk $\mathrm{N}$ efficiency in dairy cows. J. Dairy Sci. 92:3222-3232.

Kammes, K. L., and M. S. Allen. 2012. Nutrient demand interacts with forage family to affect digestion responses in dairy cows. J. Dairy Sci. 95:3269-3287.

Kendall, C., C. Leonardi, P. C. Hoffman, and D. K. Combs. 2009. Intake and milk production of cows fed diets that differed in dietary neutral detergent fiber and neutral detergent fiber digestibility. J. Dairy Sci. 92:313-323.

Kononoff, P. J., A. J. Heinrichs, and D. R. Buckmaster. 2003. Modification of the Penn State forage and total mixed ration particle separator and the effects of moisture content on its measurements. J. Dairy Sci. 86:1858-1863.

Kuoppala, K., M. Rinne, S. Ahvenjarvi, J. Nousiainen, and P. Huhtanen. 2010. The effect of harvesting strategy of grass silage on digestion and nutrient supply in dairy cows. J. Dairy Sci. 93:3253-3263.

Kuoppala, K., M. Rinne, J. Nousiainen, and P. Huhtanen. 2008. The effect of cutting time of grass silage in primary growth and regrowth and the interactions between silage quality and concentrate level on milk production of dairy cows. Livest. Sci. 116:171-182.

Lopes, F., D. E. Cook, and D. K. Combs. 2015a. Validation of an in vitro model for predicting rumen and total-tract fiber digestibility in dairy cows fed corn silages with different in vitro neutral detergent fiber digestibilities at 2 levels of dry matter intake. J. Dairy Sci. 98:574-585.

Lopes, F., D. E. Cook, and D. K. Combs. 2015b. Effects of varying ratios of corn silage to alfalfa silage on digestion of neutral detergent fiber in lactating dairy cows. J. Dairy Sci. 98:6291-6303.

Lopes, F., K. Ruh, and D. K. Combs. 2015c. Validation of an approach to predict total-tract fiber digestibility using a standardized in vitro technique for different diets fed to high-producing cows. J. Dairy Sci. 98:2596-2602.

National Forage Testing Association (NFTA). 1993. Forage analysis procedures. Method 2.2.2.5. NFTA, Lincoln, NE.

NorFor. 2011. The Nordic Feed Evaluation System. European Federation of Animal Science. Wageningen Academic Publishers, Wageningen, the Netherlands.

NRC. 2001. Nutrient Requirements of Dairy Cattle. 7th rev. ed. Natl Acad. Sci., Washington, DC.

Pelletier, S., G. F. Tremblay, G. Belanger, A. Bertrand, Y. Castonguary, D. Pageau, and R. Drapeau. 2010. Forage nonstructural carbohydrates and nutritive value as affected by time of cutting and species. Agron. J. 102:1388-1398.

Rinne, M., P. Huhtanen, and S. Jaakkola. 2002. Digestive processes of dairy cows fed silages harvested at four stages of grass maturity. J. Anim. Sci. 80:1986-1998.

Strahan, S. R., R. W. Hemken, J. A. Jackson, R. C. Buckner, L. P Bush, and M. R. Siegel. 1987. Performance of lactating dairy cows fed tall fescue forage. J. Dairy Sci. 70:1228-1234.

Turnbull, G. W., D. W. Claypool, and E. G. Dudley. 1982. Performance of lactating dairy cows fed alfalfa hays graded by relative feed value system. J. Dairy Sci. 65:1205-1211.

Van Soest, P. J., J. B. Robertson, and B. A. Lewis. 1991. Methods of dietary fiber, neutral detergent fiber and non-polysaccharides in relation to animal nutrition. J. Dairy Sci. 74:3583-3597.

Verbeten, W. D. 2012. Utilizing tall fescue and meadow fescue grasses in high production dairy rations and in binary mixtures with alfalfa. MS Thesis. University of Wisconsin-Madison.

Wildman, E. E., G. M. Jones, P. E. Wagner, R. L. Boman, H. F. Troutt, and T. N. Lesch. 1982. A dairy cow body condition scoring system and its relationship to selected production characteristics. J. Dairy Sci. 65:495-501. 